\title{
Umowa wspólnego rachunku bankowego i dziedziczenie zgromadzonych na nim środków
}

\author{
Joint account agreement and the issue of inheriting the share \\ of the deceased holder
}

\section{Wprowadzenie}

Umowa rachunku wspólnego wykształciła się w prawie polskim w odpowiedzi na praktyczne potrzeby posiadaczy środków pieniężnych związane z łączącymi ich stosunkami rodzinnymi lub gospodarczymi. Posiadanie wspólnego rachunku bankowego ułatwia rozliczenia w ramach zarządzania wspólnymi aktywami oraz kontrolę nad nimi, w szczególności w stosunkach majątkowych małżeńskich czy pomiędzy partnerami prowadzącymi wspólnie działalność gospodarczą w formie spółek cywilnych. Z kręgu podmiotów uprawnionych do zawierania umów tego rodzaju w dalszym ciągu jednak wyłączone są osoby prawne. Szereg regulacji pozakodeksowych doprowadził do poszerzenia katalogu posiadaczy rachunków wspólnych, powodując dalsze rozczłonkowanie regulacji zawartej już w Kodeksie cywilnym oraz ustawie - Prawo bankowe. W powyższym kontekście refleksji wymaga kwestia, czy nadal istnieje uzasadnienie dla utrzymania wspomnianego ograniczenia dla osób prawnych. W aktualnym stanie prawnym najbardziej precyzyjna regulacja odnosi się do rachunku wspólnego dla osób fizycznych, jednak również i w tej materii obowiązujące przepisy nie rozstrzygają wielu wątpliwości. Do najczęściej spotykanych problemów w praktyce funkcjonowania rachunku wspólnego należą kwestie następstwa prawnego oraz dalszych losów samego rachunku na wypadek śmierci jednego ze współposiadaczy. Jako że brak jest szczegółowej regulacji w tym przedmiocie, brak jednolitości również w praktyce bankowej. Po śmierci jednego ze współposiadaczy jego udział w rachunku podlega dziedziczeniu, jednakże do czasu definitywnego ustalenia kręgu 
spadkobierców zdarza się, iż tytułem zabezpieczenia ich praw banki dokonują blokady środków wchodzących w skład spadku po zmarłym, ograniczając tym samym prawo pozostałego przy życiu posiadacza do dysponowania rachunkiem. Równie często zdarza się, iż umowę rachunku wspólnego uważa się wówczas za rozwiązaną z mocy prawa lub przekształconą w umowę rachunku indywidualnego, do którego spadkobiercy nie mogą mieć dostępu. Mając na względzie zasygnalizowane powyżej wątpliwości, opierając się na poglądach wyrażonych $\mathrm{w}$ doktrynie oraz orzecznictwie, z uwzględnieniem znaczenia powyższych kwestii dla praktyki funkcjonowania sektora bankowego w niniejszej publikacji:

- dokonano analizy zmian w przepisach dotyczących rachunku wspólnego oraz oceny jakości tej regulacji, jak i uzasadnienia dla utrzymania ograniczeń podmiotowych kręgu jego posiadaczy poprzez wyłączenie osób prawnych;

- zbadano, czy obowiązująca regulacja jest zadowalająca w odniesieniu do zagadnień związanych $\mathrm{z}$ następstwem prawnym, a jeśli nie - w jakim zakresie wymaga zmian;

- zmierzono się z odpowiedzią na pytanie, czy w obowiązującym stanie prawnym po śmierci współposiadacza rachunku wspólnego umowa ta ulega rozwiązaniu z mocy prawa, czy też trwa z udziałem następców prawnych. We wstępnej części artykułu przedstawiono regulacje dotyczące rachunku wspólnego, opierając się na metodzie dogmatycznej z uwzględnieniem analizy historycznej. Dalsze rozważania prowadzone były głównie przy zastosowaniu metody funkcjonalnej.

\section{Rachunek wspólny w obowiązującym stanie prawnym}

W pierwotnym brzmieniu ustawy - Prawo bankowe (ustawa - Prawo bankowe, 1997) art. 52 przewidywał możliwość prowadzenia wspólnych rachunków bankowych w formie rachunków oszczędnościowych. Mógłby być on prowadzony dla kilku osób, z których każda korzystała z uprawnień posiadacza rachunku w granicach określonych w umowie. Ówczesne brzmienie przepisu zawężało zatem możliwość prowadzenia rachunku wspólnego tylko do rachunków typu oszczędnościowego. W literaturze (Smykla, 2011, komentarz do art. 52 ustawy - Prawo bankowe) pojawiały się jednak głosy przemawiające za tym, iż można by uznać za dopuszczalne prowadzenie rachunków wspólnych również o charakterze nieoszczędnościowym. Przepis nasuwał również wątpliwości co do kręgu podmiotów uprawnionych do zawarcia umowy rachunku wspólnego. 
Zamieszczone w nim wyrażenie „kilka osób” nie precyzowało bowiem jasno, czy chodzi wyłącznie o osoby fizyczne, czy także o osoby prawne i tzw. ułomne osoby prawne. W odpowiedzi na postulaty doktryny w przedmiocie doprecyzowania ustawy w tym zakresie, nowelizacją z dnia 23 sierpnia 2001 r. zmieniono treść art. 52 poprzez uściślenie, iż rachunek taki może być prowadzony dla kilku osób fizycznych. Usunięto również wyraz „oszczędnościowy”, który wprowadzał wątpliwość co do ograniczenia zakresu zastosowania przepisu do rachunków tego typu. Dopuszczono tym samym lub raczej przesądzono o możliwości prowadzenia jako rachunków wspólnych nie tylko jako rachunków oszczędnościowych, lecz wszystkich typów rachunków wymienionych w ustawie - Prawo bankowe. Skonkretyzowano także zakres podmiotowy dyspozycji niniejszego przepisu, zawężając go wyłącznie do osób fizycznych. Ustawa nie określa rodzaju powiązań pomiędzy osobami fizycznymi, które przesądzałyby o możliwości posiadania wspólnego rachunku bankowego. Rodzaj więzi pomiędzy tymi osobami jest z prawnego punktu widzenia obojętny. Najczęściej spotykanym rodzajem powiązań osób decydujących się na zawarcie tego typu umowy są małżonkowie, osoby pozostające w stałym związku nieformalnym czy też prowadzące wspólnie działalność gospodarczą w formie spółki cywilnej. Nie ma jednakże przeszkód, aby rachunek taki posiadały dowolne dwie (i więcej) osoby fizyczne, z jakiegokolwiek uzasadnionego dla nich powodu, chociażby brak było pomiędzy nimi powiązań o charakterze rodzinnym czy gospodarczym (Sikorski, 2006, 3.3, Lex).

Kolejne zmiany przyniosła nowelizacja ustawy - Prawo bankowe w 2004 r., w której postanowienia dotyczące rachunków wspólnych przeniesiono z art. 52 do art. 51, tytułem zaś uszczegółowienia regulacji w tym zakresie dodano nowe przepisy w art. 5la i 51b. Nowy art. $51 \mathrm{w}$ brzmieniu przewidzianym ustawą $\mathrm{z}$ dnia 1 kwietnia 2004 r. o zmianie ustawy - Prawo bankowe (Ustawa o zmianie ustawy - Prawo bankowe oraz o zmianie innych ustaw, 2004) stanowił, że rachunek bankowy może być prowadzony dla kilku osób fizycznych albo kilku jednostek samorządu terytorialnego. Niniejsza regulacja poszerzyła zatem krąg podmiotów uprawnionych do posiadania rachunków wspólnych o jednostki samorządu terytorialnego (zob. Góral, Karlikowska, Koperkiewicz-Mordel, 2006, s. 159; Kawulski, 2013, komentarz do art. 51(b) ustawy - Prawo bankowe; Mikos-Sitek, Zapadka, 2011, s. 136; Panowicz-Lipska, Radwański, 2005, komentarz do art. 51(b) ustawy - Prawo bankowe)1. Zgodnie z art. 51b ust. 1 ustawy - Prawo bankowe

${ }^{1}$ Co prawda przepis wymienia osoby fizyczne obok jednostek samorządu terytorialnego jako kategorie podmiotów uprawnione do zawarcia umowy rachunku wspólnego, niedopuszczalne jest jednak prowadzenie takiego rachunku dla osób fizycznych i jednostek samorządu terytorialnego. Doktryna wyklucza także możliwość prowadzenia rachunku dla jednostek samorządu teryto- 
rachunek wspólny dla jednostek samorządu terytorialnego może być prowadzony wyłącznie w związku ze wspólnym wykonywaniem zadań publicznych, w tym dla realizacji przedsięwzięć współfinansowanych ze środków Unii Europejskiej. Cel, dla którego taki rachunek jest prowadzony, musi być określony w umowie rachunku wspólnego (art. 51b ust. 2). W dalszym ciągu utrzymano jednak ograniczenie katalogu posiadaczy rachunku wspólnego w postaci wyłączenia z ich kręgu osób prawnych, co zdaniem J. Pisulińskiego stanowi nieuzasadnione ograniczenie swobody umów. Niedopuszczalne jest bowiem zawarcie umowy rachunku wspólnego przez osobę fizyczną i osobę prawną, w konsekwencji czego literalna wykładnia przepisu prowadzi do wniosku, iż rachunku takiego nie może posiadać spółka cywilna, której wspólnikiem jest chociażby jedna osoba prawna (Pisuliński, 2005).

Dodatkowa kategoria podmiotów uprawnionych do korzystania z instytucji rachunku wspólnego została wprowadzona nowelizacją ustawy - Prawo bankowe z dnia 11 lipca 2014 r. w postaci stron umowy o współpracy w rozumieniu ustawy - Prawo geologiczne i górnicze (ustawa - Prawo geologiczne i górnicze, 2001) $)^{2}$. Przepis art. 49zp tego aktu normatywnego ustanawiał bowiem wymóg dla posługiwania się rachunkiem wspólnym przez strony umowy o współpracy w rozumieniu prawa geologicznego i górniczego przy dokonywaniu rozliczeń i płatności dla działalności objętej umową o współpracy oraz koncesją na poszukiwanie i rozpoznawanie złoża węglowodorów oraz wydobywanie węglowodorów ze złoża albo koncesją na wydobywanie węglowodorów ze złoża. Z. Ofiarski podkreśla, iż rachunek wspólny prowadzony dla stron umowy o współpracę jest szczególną jego postacią o wieloelementowej konstrukcji prawnej. Do jego posiadania bowiem niezbędne są koncesja na prowadzenie działalności w zakresie poszukiwania i rozpoznawania złóż węglowodorów oraz wydobywania węglo-

rialnego i spółek handlowych utworzonych przez te jednostki, nawet jeśli podmioty te realizują wspólnie zadania publiczne.

2 Zgodnie z art. 49zi w ówczesnym brzmieniu ustawy poprzez umowę o współpracy strony zobowiązują się do wykonywania działalności w zakresie poszukiwania i rozpoznawania złóż lub ich wydobywania pod warunkiem uzyskania koncesji. Niniejszą ustawą dokonano wdrożenia następujących aktów prawnych Wspólnot Europejskich: dyrektywa Rady 92/91/EWG z 3.11.1992 r. dotycząca minimalnych wymagań mających na celu poprawę warunków bezpieczeństwa i ochrony zdrowia pracowników w zakładach górniczych wydobywających kopaliny otworami wiertniczymi (Dz. Urz. WE L348 z 28.11.1992 r., s. 9 z późn. zm.); dyrektywa Rady 92/104/EWG z 3.12.1992 r. w sprawie minimalnych wymagań w zakresie bezpieczeństwa i ochrony zdrowia pracowników odkrywkowego i podziemnego przemysłu wydobywczego (Dz. Urz. WE L 404 z 31.12.1992, s. 10 z późn. zm.); dyrektywy Parlamentu Europejskiego i Rady 94/22/WE z 30.05.1994 r., w sprawie warunków udzielania i korzystania z zezwoleń na poszukiwanie, badanie i produkcję węglowodorów (Dz. Urz. WE L 164 z 30.06.1994). 
wodorów ze złóż, zawarcie przez strony umowy o współpracę w tym zakresie na podstawie przepisów ustawy i umowa o ustanowieniu użytkowania górniczego. Bez któregokolwiek z tych elementów prowadzenie rachunku wspólnego nie jest możliwe (Ofiarski, 2017). Ma się tu do czynienia z sytuacją, gdzie ingerencja w treść norm ustawy - Prawo bankowe ma niewiele wspólnego z ratio legis przepisu czy wolą ustawodawcy, lecz została wymuszona przez zmiany w odrębnej ustawie dokonane na skutek harmonizacji prawa unijnego.

Kolejną z nowelizacji, która wymusiła zmiany w regulacji zawartej w art. 51 ustawy - Prawo bankowe, była nowela do Kodeksu rodzinnego i opiekuńczego z dnia 10 czerwca 2016 r. (Ustawa o zmianie ustawy kodeks rodzinny i opiekuńczy oraz niektórych innych ustaw, 2016), wprowadzająca do katalogu rachunków bankowych tzw. rachunek rodzinny, czyli nowy rodzaj rachunku bankowego prowadzonego dla osób fizycznych, którym przyznano niepodlegające egzekucji świadczenia, dodatki, zasiłki oraz inne przysporzenia wskazane w art. $833 \$ 6$ i 7 k.p.c. Jest to szczególny typ rachunku bankowego prowadzony wyłącznie dla osób fizycznych, na który wpływają należne im środki pochodzące z rozmaitych świadczeń, tj. świadczenia wychowawczego, wpłat z funduszu alimentacyjnego, świadczeń z tytułu pomocy społecznej i programu 500 plus lub świadczeń na rzecz małoletnich umieszczonych w pieczy zastępczej (Kowalewska, Pisarewicz, $2017)^{3}$. Znowelizowana na tej podstawie treść art. 51 ustawy- Prawo bankowe stanowi, iż wyłączona jest możliwość prowadzenia tego typu rachunku w formie rachunku wspólnego. Wyłączenie to wynika z osobistego charakteru przyznanych świadczeń oraz ich szczególnej ochrony przed egzekucją, wyrażenie zaś go explicite w ustawie uznać należy za właściwy zabieg legislacyjny, gdyż nie pozostawia pola do interpretacji w kwestii wykładni przepisu pod kątem dopuszczalności prowadzenia tego typu rachunku dla kilku spokrewnionych osób lub beneficjentów i ich przedstawicieli ustawowych.

Ostateczny krąg podmiotów, któremu obowiązująca aktualnie regulacja przyznaje uprawnienie do zawierania umów rachunku wspólnego, ukształtowała ustawa z dnia 16 maja 2019 r. o zmianie ustawy o pracowniczych planach kapitałowych, ustawy o organizacji i funkcjonowaniu funduszy emerytalnych oraz ustawy - Prawo bankowe (Ustawa o zmianie ustawy o pracowniczych planach kapitałowych, ustawy o organizacji i funkcjonowaniu funduszy emerytalnych oraz ustawy - Prawo bankowe, 2019), którą do katalogu podmiotów wymienionych $\mathrm{w}$ art. 51 dodano fundusze emerytalne będące funduszami zdefiniowanej daty

3 Z zawarciem umowy rachunku rodzinnego, jak i jego prowadzeniem nie są powiązane żadne opłaty ani prowizje, a środki zgromadzone na tym rachunku są zwolnione od egzekucji (wolne od zajęcia). 
w rozumieniu ustawy z dnia 4 października 2018 r. o pracowniczych planach kapitałowych (Ustawa o pracowniczych planach kapitałowych, 2018), zarządzane przez jedno powszechne towarzystwo emerytalne. Jest to konstrukcja kwalifikowana, podobnie jak w przypadku stron umowy o współpracy w rozumieniu prawa geologicznego i górniczego, która uzależnia uprawnienie do zawarcia umowy rachunku wspólnego od spełnienia przesłanek wymienionych w innej ustawie, w tym przypadku ustawie o pracowniczych planach kapitałowych. Po raz kolejny zatem do kręgu potencjalnych posiadaczy rachunku wspólnego włączono dodatkową kategorię podmiotów, utrzymując jednak w dalszym ciągu wyłączenie z niej osób prawnych.

W rezultacie najczęściej spotykana w praktyce postać rachunku wspólnego to rachunek, którego współposiadaczami są osoby fizyczne - przeważnie małżonkowie lub osoby pozostające faktycznie we wspólnym pożyciu. Ustawa nie różnicuje w tym względzie związków małżeńskich i relacji o charakterze niesformalizowanym, w tym związków jednopłciowych, gdyż jak wspomniano na wstępie, rachunek wspólny jest dostępny dla jakichkolwiek osób fizycznych, niezależnie od rodzaju (lub braku) łączącej ich więzi prawnorodzinnej, np. dla rodziców i dzieci (zob. Wyrok SA w Poznaniu z 30.06.2010 r., I ACa 504/10; Wyrok SO w Tarnowie z 15.03.2017, I C 908/16). Często spotyka się również rachunki wspólne prowadzone dla przedsiębiorców - osób fizycznych prowadzących działalność gospodarczą w formie spółek cywilnych - należy podkreślić, iż rachunek taki nie jest rachunkiem spółki, lecz wspólnym rachunkiem wspólników (zob. NBP, 2001; Wyrok NSA z 04.06.2013, II FSK 1534/12). Ustawodawca nie przewidział jednak, że występują także inne kategorie podmiotów, które mogą być wspólnikami spółek cywilnych (Pyzioł, 2018; BFG, 2018)4 , jak chociażby spółki kapitałowe. Nie ma w doktrynie jednolitego stanowiska, czy należy traktować to jako celowe wyłączenie czy niepełną regulację (Mazur, 2007, s. 112; Zoll, 2005, komentarz do art. 51 ustawy - Prawo bankowe). Pozostawia wątpliwości również celowość takiego wyłączenia, podobnie jak wyłączenie możliwości prowadzenia rachunku wspólnego dla kilku osób prawnych. W doktrynie (Monkiewicz, 2014) wskazuje się również na wątpliwości, czy w przypadku, gdy w drodze dziedziczenia testamentowego spadkobiercą współposiadacza jest osoba prawna (np. fundacja), umowa rachunku wspólnego sprzeczna z treścią art. 51 ustawy - Prawo

4 Bankowy Fundusz Gwarancyjny w informacji dla banków zwraca uwagę, iż wskazywanie spółki cywilnej zamiast jej wspólników jako strony umowy rachunku bankowego jest wadą formalnoprawną i konieczne jest prawidłowe ustalenie pełnego składu jej wspólników oraz zasad reprezentacji. 
bankowe trwa z udziałem osoby prawnej jako spadkobiercy, czy też zgodnie z art. 58 k.c. dotknięta jest ona sankcją nieważności.

Nie ulega wątpliwości, że instytucja wspólnego rachunku bankowego jest rozwiązaniem niezwykle wygodnym w sytuacji, gdy kilka podmiotów posiada potrzebę dysponowania wspólnymi środkami pieniężnymi. Dyskusyjne jest natomiast, czy ograniczenie kręgu podmiotów, które mogą posiadać taki rachunek do osób fizycznych, jednostek samorządu terytorialnego i podmiotów wymienionych w wymienionych ustawach, jest w dalszym ciągu uzasadnione. Potrzebę wprowadzenia zmian sygnalizowano m.in. w ramach prac Komisji Kodyfikacyjnej Prawa Cywilnego z inicjatywy Rady Prawa Bankowego w 2007 r. - projekt ustawy o nowelizacji Kodeksu cywilnego przewidywał wprowadzenie w trzeciej księdze k.c., w tytule XX dział II przepisów dotyczących rachunku bankowego wspólnego m.in. w zakresie rozszerzenia kręgu podmiotów mogących stać się posiadaczami takich rachunków także o osoby prawne. W uzasadnieniu do projektu wskazano również, że przepisy prawa bankowego regulujące kwestie cywilnoprawne powinny być ujęte w k.c. $z$ uwagi na niekorzystne skutki regulacji cywilnoprawnej w szeregu ustaw pozakodeksowych. Zwrócono uwagę nie tylko na związane z tym problemy natury prawnej, lecz także na fakt, iż obecny sposób regulacji polegający na rozproszeniu przepisów w wielu aktach prawnych jest szkodliwy dla praktyki obrotu oraz marginalizuje rolę k.c. w zakresie stosunków cywilnoprawnych w sektorze bankowym (uzasadnienie do projektu ustawy o zmianie Kodeksu cywilnego i niektórych innych ustaw, 2008; Pisuliński, 2012). Zasygnalizowano także, że brak dostępności rachunku wspólnego dla wszystkich podmiotów prawa cywilnego uniemożliwia w Polsce rozwój instytucji tzw. cash poolingu, czyli wspólnego zarządzania finansami przez podmioty powiązane kapitałowo, m.in. w postaci koncentrowania środków pieniężnych należących do kilku podmiotów na jednym rachunku oraz kompensowania przejściowych nadwyżek finansowych wykazywanych przez niektóre z nich z okresowymi niedoborami finansowymi u innych (Zwyrtek, 2006). Cel w postaci usunięcia wątpliwości co do braku ograniczeń posiadania rachunku wspólnego przez osoby prawne miałby zostać osiągnięty poprzez uchylenie art. 51 ustawy - Prawo bankowe. Należy przychylić się do argumentacji zawartej w projekcie ustawy, jak i w rozważaniach przedstawicieli doktryny (Drela, Stangret-Smoczyńska, 2010), iż zwłaszcza $\mathrm{z}$ uwagi na praktykę bankową opowiedzenie się za dopuszczalnością zawierania umów rachunku wspólnego również przez osoby prawne nie powinno przybierać formy przyjęcia odmiennej wykładni przepisu art. 51 Prawa bankowego (która jest przez banki dokonywana a contrario), lecz definitywnego wyeliminowania z obrotu. Projekt ustawy nie spotkał się jednak 
z uznaniem Ministerstwa Finansów. Zespół Legislacyjny Związku Banków Polskich informował, że już na etapie konsultacji międzyresortowych proponowane regulacje spotkały się z wyraźnym sprzeciwem $\mathrm{z}$ uwagi na fakt, iż w odniesieniu do rachunków wspólnych typu łącznego trudno jest ustalić precyzyjnie strony transakcji, a w szczególności jej beneficjenta, jak również posługiwanie się tego typu rachunkami mogłoby skutkować brakiem przejrzystości w źródłach finansowania tych podmiotów oraz w sferze prawnopodatkowej. W konsekwencji Ministerstwo Finansów zarekomendowało wstrzymanie prac nad projektem (ZBP, 2012). W odpowiedzi na tak rygorystyczne stanowisko Komisja rozważała modyfikację projektu poprzez doprecyzowanie, iż prowadzenie wspólnych rachunków przez osoby prawne miałoby być dozwolone wyłącznie dla realizacji wspólnych przedsięwzięć gospodarczych, na podobieństwo konstrukcji rachunku wspólnego prowadzonego dla jednostek samorządu terytorialnego w celu wspólnego wykonania zadania publicznego. Zespół Legislacyjny Związku Banków Polskich informował, iż w pracach Komisji Kodyfikacyjnej rozważano wprowadzenie obowiązku wskazania w umowie wielkości udziałów każdego ze współposiadaczy oraz zakazu prowadzenia rachunków wspólnych dla osób prowadzących działalność gospodarczą i osób niebędących przedsiębiorcami (ZBP, 2012). Niezależnie od kierunków zmian w regulacji rachunku bankowego wspólnego należy zgodzić się z postulatami sektora bankowego, iż modyfikacja w zakresie udostępnienia tej instytucji szerszemu kręgowi podmiotów jest potrzebna i uzasadniona gospodarczo. Nie można jednak odmówić słuszności zastrzeżeniom dotyczącym ewentualnych niekorzystnych konsekwencji na płaszczyźnie przejrzystości źródeł finansowania osób prawnych oraz sfery podatkowej. Mając na względzie nadmierne rozproszenie regulacji w k.c. i ustawach okołokodeksowych, wydaje się, iż jakakolwiek kolejna nowelizacja winna zostać przeprowadzona w sposób kompleksowy, na korzyść k.c.

\section{2. Śmierć współposiadacza rachunku wspólnego}

Umowa rachunku wspólnego jest szczególną postacią umowy rachunku bankowego, która podlega nie tylko przepisom ustawy - Prawo bankowe, ale jako odrębny typ umowy nazwanej regulowana jest przepisami k.c. (art. 725-733) (ustawa - Kodeks cywilny, 1964; Gudowski, 2017, komentarz do art. 725 k.c.; Kidyba, 2014, komentarz do art. 725 k.c.; Pietrzykowski, 2011, komentarz do art. 725 k.c.) jako klasyczny stosunek prawny o charakterze obligacyjnym (zob. 
Gniewek, 2010, komentarz do art. 725 k.c.) $)^{5}$. Na słabość regulacji w zakresie umowy rachunku bankowego wskazuje sam fakt jej rozczłonkowania pomiędzy przepisy k.c., przepisy zawarte w ustawie - Prawo bankowe, jak i ustawy z dnia 19 sierpnia 2011 r. o usługach płatniczych, do której odesłanie znajduje się w art. 52 ustawy - Prawo bankowe - wskazuje się jednak, iż przepisy ustawy - Prawo bankowe mają wyłącznie charakter uzupełniający względem regulacji zawartej w k.c. i nie należy ich traktować jako modyfikacji przepisów art. 725-733 k.c., lecz ich uszczegółowienie (zob. Nowak, 2018, s. 566; Osajda, 2016, komentarz do art. 725 k.c.). Liczne zmiany w prawie bankowym są rezultatem zmian dokonanych w innych aktach prawnych, co czyni z regulacji umowy rachunku bankowego unormowanie nad wyraz złożone - szczególnie w odniesieniu do umowy rachunku wspólnego. Ponadto, iż sama umowa rachunku bankowego jest umową kwalifikowaną podmiotowo ${ }^{6}$, w odniesieniu do umowy rachunku wspólnego określone kwalifikacje występują po obu stronach stosunku zobowiązaniowego, jako że podmioty uprawnione do zawarcia tej umowy zostały enumeratywnie wskazane w treści art. 51 ustawy - Prawo bankowe. I tak najczęściej rachunek wspólny powstaje na skutek intencjonalnego zawarcia umowy przez dwa lub więcej podmiotów wymienionych w ustawie po jednej oraz bank po drugiej stronie. Zdarza się jednak, że przekształceniu w rachunek wspólny ulega indywidualny rachunek bankowy w konsekwencji śmierci jego posiadacza i wstąpienia spadkobierców w jego prawa i obowiązki. Analogicznie, możliwe jest dalsze rozszerzanie kręgu współposiadaczy rachunku wspólnego wskutek śmierci któregokolwiek z nich (Pyzioł, 1997) ${ }^{7}$ Zasadność dalszego trwania umowy rachunku wspólnego w tym kształcie budzi jednak poważne wątpliwości, gdyż prowadzi do posiadania jednego rachunku przez osoby, których wzajemne więzi nie uzasadniają wspólnego przechowywania środków pieniężnych i korzystania z nich, o czym będzie mowa w dalszej części opracowania.

5 W doktrynie można również spotkać się z poglądami, że pojęcie rachunku bankowego można rozumieć dwojako. Rozróżnia się tu definicję rachunku bankowego w ujęciu formalnym, to jest odzwierciedlenia stosunku prawnego w księgach banku, w formie konta bankowego, na którym odnotowywane są dyspozycje pieniężne dokonywane w ciężar salda rachunku, jak i sam stosunek prawny w ujęciu materialnym, z tytułu którego bank prowadzi operacje techniczne ewidencjonowane w systemie.

${ }^{6}$ Jedną ze stron transakcji jest określony rodzajowo podmiot - bank w rozumieniu art. 2 ustawy - Prawo bankowe.

Zdaniem niektórych autorów z tą postacią rachunku ma się do czynienia, gdy rachunek bankowy indywidualny należący do zmarłego posiadacza przekształca się w rachunek wspólny wskutek dziedziczenia. Przyjmuje się, że w odniesieniu do rachunku wspólnego prowadzonego dla spadkobierców stosuje się przepisy dotyczące wspólności majątku spadkowego oraz działu spadku (Zob. Fojcik-Mastalska, 2007, s. 183). 
W orzecznictwie (Wyrok SA w Katowicach z 28.10.2010 r., III AUa 773/10; Wyrok SA w Warszawie z 27.02.2019 r., III AUa 895/17; odmienny pogląd: Wyrok SO w Warszawie z 17.05.2017 r., XIII U 7/17; Wyrok SO w Warszawie z 26.06.2017 r., XIII U 2662/16) występują również poglądy, iż rachunek wspólny traci swój byt, gdyż od daty śmierci jednego z dwojga posiadaczy nie spełnia on ustawowych wymogów rachunku wspólnego.

W obowiązujących przepisach brak jest szczegółowych uregulowań w tym przedmiocie, praktyka stosowana zaś przez banki jest bardzo niejednolita. Niezwykle często występują rozbieżności w procedowaniu względem dalszych losów samego rachunku, zwłaszcza w odniesieniu do rachunków wspólnych prowadzonych dla dwojga współposiadaczy. Za dyskusyjne uznaje się, czy rachunek taki z mocy prawa przekształca się w rachunek indywidualny żyjącego posiadacza, czy umowa rachunku bankowego ulega z mocy prawa rozwiązaniu. Spotyka się także rozwiązania przewidujące ustanowienie blokady udziału zmarłego współposiadacza do zakończenia ewentualnego postępowania spadkowego, a następnie zamknięcie rachunku i otwarcie rachunku indywidualnego na rzecz pozostałego przy życiu posiadacza. Niektóre banki uznają z kolei, iż spadkobiercy wstępują w prawa i obowiązki zmarłego i stają się współposiadaczami rachunku wspólnego. Mając na względzie powyższe wątpliwości, w projekcie zmian do k.c. z 2008 r. przewidziano wprowadzenie w tytule XX art. 733', którego pkt 3 stanowiłby, że w przypadku śmierci współposiadacza rachunku wspólnego umowa rachunku wygasa, chyba że strony postanowiły inaczej (Projekt zmian k.c., 2008), regulacja ta nie weszła jednak w życie.

W związku z brakiem przepisów szczególnych odnoszących się do postępowania względem rachunków wspólnych prowadzonych dla osób fizycznych na wypadek śmierci współposiadacza najbardziej racjonalne wydaje się wprowadzenie do praktyki bankowej procedur przewidujących uregulowanie powyższych kwestii w umowie rachunku wspólnego. Na możliwość taką wskazuje Związek Banków Polskich w biuletynie Co dzieje się z naszym kontem bankowym po śmierci? (ZBP, 2020), w którym wśród przykładowych postanowień na wypadek śmierci jednego ze współposiadaczy rachunku wskazano zastrzeżenie umowne, iż w miejsce zmarłego współposiadacza wchodzą jego spadkobiercy lub iż umowa taka ulega z mocy prawa rozwiązaniu, lub rachunek ulega przekształceniu w indywidualny rachunek żyjącego współposiadacza. Uregulowanie powyższej kwestii w umowie ograniczyłoby działanie banku wyłącznie do wykonania postanowień umownych. Wydaje się, iż najmniej dogodnym z proponowanych rozwiązań jest kontynuowanie istnienia rachunku wspólnego dla pozostałego przy życiu współposiadacza i spadkobierców zmarłego, a to z następujących 
względów. Po pierwsze rozwiązanie to wprowadza stan niepewności dla żyjącego posiadacza odnośnie do dalszych losów rachunku co najmniej na czas oczekiwania na ustalenie kręgu spadkobierców oraz uprawomocnienia się orzeczenia stwierdzającego prawa do spadku lub wylegitymowania się przez spadkobierców aktem poświadczenia dziedziczenia ${ }^{8}$. Po drugie należy spodziewać się, iż posiadacz rachunku nie będzie zainteresowany kontynuowaniem umowy rachunku wspólnego ze spadkobiercami zmarłego z uwagi na brak więzi, która łączyła go ze zmarłym i była podstawą uzasadniającą posiadanie wspólnego rachunku bankowego. Brak jest również uzasadnienia dla przystępowania przez spadkobierców do rachunku wspólnego z uwagi na potrzebę uzyskania dostępu do środków wchodzących w skład majątku spadkowego, gdyż niezależnie od powyższego żyjący współposiadacz będzie musiał rozliczyć się z tych środków względem spadkobierców, jeżeli przewyższają jego udział w spadku, lub przekazać im kwotę w wysokości udziału zmarłego, jeśli nie dziedziczy on po nim ${ }^{9}$.

Sytuacja jest bardziej skomplikowana, jeśli umowa nie zawiera postanowień na wypadek śmierci jednego z posiadaczy rachunku. Wydaje się, iż pomocne w tej sytuacji może okazać się przeanalizowanie przepisów Kodeksu postępowania

8 Odrębną kwestią nastręczającą wiele wątpliwości w praktyce bankowej jest informowanie spadkobierców o stanie środków na rachunku zmarłego oraz tajemnica bankowa, którą bank jest zobowiązany zachowywać do momentu wylegitymowania się przez spadkobierców dokumentem potwierdzającym ich prawa do spadku. Oznacza to, iż w niektórych sprawach spadkowych, gdzie ustalenie kręgu spadkobierców napotyka na trudności, czas oczekiwania na informację co do wysokości środków na rachunkach bankowych zmarłego może być znacznie wydłużony. Rozbieżności występują w praktyce również co do określania przez banki zakresu informacji, których można udzielić spadkobiercy, aby nie naruszać praw współkredytobiorców lub współposiadaczy rachunków wspólnych. W powyższej kwestii wielokrotnie wypowiadała się Komisja Nadzoru Finansowego, postulując m.in., iż zbiorcza informacja dla spadkobiercy o posiadanych przez zmarłego rachunkach bankowych nie powinna ujawniać danych współposiadacza rachunku wspólnego (zob. KNF, 2016; Wyrok SA w Warszawie z 17.10.2007 r., III AUa 961/07).

9 Zob. postanowienie SN z 07.11.1967 (I CZ 97/67, OSNCP i Uz 1968 r., Nr 8-9, poz. 145) oraz Wyrok SA w Warszawie z 11.01.2017 r. (V Ca 919/16), z których wynika, iż nic nie stoi na przeszkodzie samodzielnemu dochodzeniu przez spadkobiercę części wierzytelności spadkowej nawet przed działem spadku, a w szczególności ani przepisy dotyczące spadku, ani stosowane odpowiednio przepisy o współwłasności w częściach ułamkowych nie pozbawiają go tej możliwości, jeśli świadczenie jest podzielne. SA w Warszawie zważył ponadto, iż brak jest uzasadnienia dla przetrzymywania środków należących do zmarłego posiadacza rachunku do dokonania działu spadku, jeśli krąg spadkobierców jest znany i wynika z postanowienia o stwierdzeniu nabycia spadku, wierzytelność zaś jest podzielna. Spadkobierca, który doznałby pokrzywdzenia poprzez dokonanie wypłaty na rzecz innego spadkobiercy części przysługującej mu wierzytelności będzie bowiem mógł dochodzić ochrony w postępowaniu o dział spadku. Należy w szczególności podzielić pogląd SA w Warszawie, iż oczekiwanie do działu spadku mogłoby prowadzić do sytuacji, w której środki nigdy nie mogłyby zostać wypłacone, a to z uwagi na fakt, iż czasami odnalezienie współspadkobierców napotyka na znaczne trudności lub jest niemożliwe. 
cywilnego (ustawa - Kodeks cywilny, 1964) dotyczących egzekucji z rachunków bankowych. Art. $891^{1} \$ 1$ k.p.c. stanowi, że czynności egzekucyjne prowadzone z rachunku wspólnego dłużnika prowadzone są do przypadającego dłużnikowi udziału w rachunku, stosownie do treści umowy regulującej prowadzenie rachunku - jeżeli zaś umowa nie określa udziału w rachunku wspólnym lub gdy dłużnik nie przedłoży jej komornikowi, domniemywa się, że udziały są równe. Podobnie jest w przypadku ogłoszenia upadłości konsumenckiej względem jednego ze współposiadaczy - jeśli rachunek nie był prowadzony dla małżonków pozostających we wspólności ustawowej, syndyk może dysponować jedynie „udziałem” upadłego w rachunku wspólnym (Dobrzeniecka, 2016). W drodze analogii można zatem przyjąć, że w momencie, gdy w związku z postępowaniem spadkowym środki należące do jednego ze współposiadaczy mają być przekazane innemu podmiotowi (lub podmiotom), konieczne jest uprzednie ustalenie udziału zmarłego w rachunku. Udział ten może zostać określony w umowie rachunku bankowego, $\mathrm{w}$ braku zaś postanowień $\mathrm{w}$ tym przedmiocie należałoby przyjąć, iż udziały wszystkich współposiadaczy są równe. Mamy więc jasność, iż nie wszystkie środki zdeponowane na rachunku wspólnym stanowić będą przedmiot postępowania spadkowego. Interesować nas będzie wyłącznie udział przysługujący zmarłemu współposiadaczowi. W tym zakresie prawa pozostałych współposiadaczy do dysponowania środkami zgromadzonymi na rachunku mogą zostać istotnie ograniczone. Niektóre banki dokonują tzw. blokady środków, tj. wyłączenia ich z puli środków, którymi dysponować mogą pozostali współposiadacze. Zdarza się jednak, iż blokada dotyczy całego rachunku, co zamyka pozostałym współposiadaczom dostęp do wszystkich zgromadzonych na nim środków aż do zakończenia postępowania spadkowego. Rozwiązanie takie jest niedopuszczalne, czemu wyraz dał m.in. Związek Banków Polskich we wspomnianym biuletynie. Należy podkreślić, że blokada środków może być dokonana tylko do wysokości udziału przysługującego zmarłemu współposiadaczowi, podobnie jak zajęcie komornicze w postępowaniu egzekucyjnym utrzymuje się tylko w odniesieniu do udziału dłużnika, przy jednoczesnym zwolnieniu pozostałych udziałów spod egzekucji. W procedurach bankowych spotyka się również pogląd, że blokadzie może podlegać zarówno udział zmarłego współposiadacza, jak i odsetki obliczone dla tego udziału na dzień jego śmierci. Nie ma natomiast wątpliwości, że pomimo istnienia blokady pozostali współposiadacze mogą w dalszym ciągu bez ograniczeń dysponować resztą środków zgromadzonych na rachunku na zasadach takich, jak do tej pory. W doktrynie (Zoll, 2005, s. 430) występuje też bardziej rygorystyczne stanowisko dotyczące zakazu blokady środków, nawet do wysokości udziału zmarłego współposiadacza - podnosi się, że blokowanie 
rachunku jest zarówno niedopuszczalne, jak i niecelowe, gdyż to nie bank jest gwarantem wypłaty środków na rzecz spadkobierców zmarłego współposiadacza. Nie może on również we własnym zakresie dokonywać „działu spadku” ani nie jest on uprawniony do wiążącego ustalania, jaka ilość środków w wewnętrznym rozrachunku przypada każdemu ze współposiadaczy, a co za tym idzie - spadkobiercom każdego z nich. Należałoby zatem uznać, że w chwili powzięcia przez bank wiadomości o śmierci jednego ze współposiadaczy, bank nie może zablokować środków zgromadzonych na rachunku, chociażby inni współposiadacze mieli korzystać z całości kapitału. Kwestia późniejszych wzajemnych rozliczeń pozostającego przy życiu współposiadacza oraz spadkobierców zmarłego pozostaje tu poza zainteresowaniem banku.

Nie pozostawia wątpliwości fakt, że nie należy doprowadzać do sytuacji, w której z powodu śmierci jednego współposiadacza żyjący posiadacz rachunku zostaje odcięty od środków zdeponowanych na rachunku i nie może realizować wierzytelności przysługującej mu względem banku (Mazur, 2007, s. 116; Zoll, 2005, s. 430). Nie sposób jednak rozstrzygnąć, czy zakaz blokowania środków powinien dotyczyć całości kapitału zgromadzonego na rachunku, czy tylko udziału spadkodawcy. Z jednej strony należałoby pozytywnie ocenić częściowe blokowanie rachunku w celu zabezpieczenia interesów spadkobierców, jednakże należy pamiętać o tym, że żaden przepis nie nakłada na bank takiego obowiązku. Z drugiej strony, pozostawienie całości środków do dyspozycji żyjącego współposiadacza nie jest de facto działaniem na rzecz nieuprawnionego (zwłaszcza jeśli ma się do czynienia z rachunkiem wspólnym typu rozłącznego), gdyż może on samodzielnie rozporządzać wszystkimi środkami bez zgody pozostałych współposiadaczy. Brak jednak jednolitego stanowiska odnośnie do sytuacji, gdy dziedziczeniu podlega udział w rachunku wspólnym łącznym. Wydaje się, że jest to jedyna prawnie dopuszczalna sytuacja, w której pozostały przy życiu współposiadacz zostałby pozbawiony dostępu do rachunku do czasu zakończenia postępowania spadkowego. Jeżeli bowiem w umowie rachunku bankowego strony postanowiły, że do dysponowania środkami zgromadzonymi na rachunku potrzebne jest zgodne oświadczenie wszystkich współposiadaczy, do czasu skutecznego wstąpienia spadkobierców w prawa i obowiązki zmarłego takie zgodne oświadczenie woli nie może zostać uzyskane. Wydaje się jednak, iż koncepcja ta godzi w niedopuszczalnym stopniu w interesy żyjącego posiadacza rachunku.

Komentarza wymaga również przytoczone wcześniej stanowisko, iż rachunek wspólny może powstać wskutek dziedziczenia indywidualnego rachunku bankowego należącego do spadkodawcy (Fojcik-Mastalska, 2007, s. 183). Rachunek taki miałby być rachunkiem typu łącznego oraz podlegać przepisom o dziale 
spadku, tj. art. 1035 k.c. O ile w odniesieniu do rachunku, który dopiero staje się wspólnym w wyniku śmierci posiadacza, można sobie wyobrazić praktyczne zastosowanie powyższego rozwiązania, o tyle nie może być o tym mowy, gdy jak wskazano wyżej - dziedziczeniu podlega jedynie udział w rachunku, który jest już rachunkiem wspólnym. Nie można bowiem pogodzić dwóch sposobów dysponowania środkami na rachunku i przyznać części współposiadaczy uprawnienia do dysponowania całością środków (współposiadacz pierwotny), a na część nałożyć obowiązek uzyskiwania zgody wybranych współposiadaczy spadkobierców zmarłego współposiadacza. W praktyce istnieją również wątpliwości co do tego, czy powstały w ten sposób rachunek wspólny powinien trwać pomiędzy spadkobiercami nawet po zakończeniu postępowania spadkowego. Nie wydaje się bowiem uzasadnione, aby stan taki utrzymywał się dłużej niż to konieczne ze względu na przebieg postępowania spadkowego, gdyż istnieje nikłe prawdopodobieństwo, że nieposiadający wspólnych interesów finansowych spadkobiercy zapewnią wpływy na niniejszy rachunek i będą korzystać z niego wspólnie. Specyfika rachunku wspólnego w dużej mierze wynika ze wspólnych interesów ekonomicznych podmiotów, które decydują się na gromadzenie środków na jednym rachunku dla ułatwienia wzajemnych rozliczeń lub wspólnego korzystania z należących do nich środków - nie wydaje się zatem zasadne, aby rachunek wspólny spadkobierców utrzymywał się także po zakończeniu postępowania spadkowego i dokonania działu spadku. Najczęściej bowiem ukształtowany w ten sposób krąg współposiadaczy nie będzie oparty na żadnej racjonalnej podstawie uzasadniającej wspólne gromadzenie środków na przyszłość, jak i wspólne z nich korzystanie.

Zarówno piśmiennictwo, jak i praktyka bankowa nie udzielają jednoznacznej odpowiedzi na pytanie, co dzieje się z rachunkiem wspólnym po przeprowadzeniu postępowania spadkowego i przekazaniu środków stanowiących udział zmarłego jego spadkobiercom, jeśli w wyniku jego śmierci pozostał przy życiu tylko jeden posiadacz rachunku. Oczywiste jest, że rachunek ten nie może dalej egzystować w formie rachunku wspólnego. W tej sytuacji w praktyce spotyka się dwa rozwiązania: uznaje się, że rachunek z mocy prawa przekształca się w rachunek indywidualny pozostałego przy życiu współposiadacza lub dokonuje się zamknięcia takiego rachunku i jednoczesnego otwarcia nowego rachunku indywidualnego dla pozostałego przy życiu współposiadacza. Wydaje się jednak, że rozstrzygnięcie, która z wyżej zaproponowanych opcji jest bardziej prawidłowa, nie ma większej doniosłości w sferze prawnej. Bezsporne jest bowiem, iż dalszy byt rachunku wspólnego nie jest możliwy, żyjący współposiadacz zaś winien odtąd dysponować pozostałymi środkami na osobistym rachunku 
bankowym typu indywidualnego. Fakt, czy usankcjonowanie bytu tej formy rachunku nastąpi już w samej umowie czy poprzez jej rozwiązanie wolą stron, $\mathrm{z}$ jednoczesnym zawarciem nowej umowy rachunku indywidualnego, nie ma większego znaczenia. Każda z tych dróg doprowadzi bowiem do ukształtowania stosunku zobowiązaniowego $\mathrm{w}$ formie typowej umowy rachunku bankowego indywidualnego. Mając na względzie powyższe rozważania, należałoby przyjąć, iż praktyka bankowa powinna raczej zmierzać w kierunku rozstrzygania o losach rachunku wspólnego po śmierci współposiadaczy w samej umowie rachunku poprzez zawarcie w niej postanowień przewidujących rozwiązanie takiej umowy lub przekształcenie rachunku w rachunek indywidualny. Korzystając z dobrodziejstw regulacji ius dispositivum $\mathrm{z}$ art. 5la prawa bankowego, dla uniknięcia wątpliwości interpretacyjnych oraz stanu niepewności co do sytuacji żyjącego współposiadacza kwestie te powinny być elementem treści porozumienia stron, chociażby jako element wzorca umowy lub postanowień regulaminu.

\section{Zakończenie}

Mając na względzie powyższe rozważania, należy wskazać, iż aktualnie obowiązujące przepisy dotyczące rachunku wspólnego są nadmiernie rozproszone i mało przejrzyste. Dotychczasowe zabiegi legislacyjne doprowadziły do nieuzasadnionego, wybiórczego poszerzenia katalogu posiadaczy rachunku wspólnego o podmioty wymienione $\mathrm{w}$ innych ustawach, $\mathrm{z}$ dalszym pominięciem osób prawnych. Nie umniejszając zasadności wątpliwości w kwestii ewentualnych konsekwencji podatkowych oraz przejrzystości źródeł finansowania osób prawnych, uznać należy, iż utrzymanie powyższego wyłączenia nie jest dłużej uzasadnione. Dla zapewnienia bezpieczeństwa obrotu w tym względzie w ewentualnej nowelizacji przepisów należałoby uwzględnić proponowane przez Komisję Kodyfikacyjną ograniczenia na wzór regulacji odnoszących się do rachunku wspólnego prowadzonego dla jednostek samorządu terytorialnego. W kwestii zaś ograniczenia rozproszenia przepisów dotyczących rachunku wspólnego wskazać należy, iż regulacje te winny zostać usunięte z ustawy - Prawo bankowe oraz włączone do k.c. Z uwagi jednak na specyfikę regulacji odnoszących się do rachunku wspólnego prowadzonego dla stron umowy o współpracy w rozumieniu Prawa geologicznego bardziej zasadne wydaje się pozostawienie ich w tejże ustawie, z odwołaniem do należycie usystematyzowanych przepisów ogólnych dotyczących rachunku wspólnego zawartych w znowelizowanym k.c. 
Choć przepisy k.c. nie pozostawiają wątpliwości w kwestii zasad dziedziczenia majątku zmarłego, jak i praw spadkobierców do dysponowania spadkiem tak przed, jak i po dokonaniu działu spadku, w zderzeniu z praktyką bankową w odniesieniu do rachunku wspólnego prowadzonego dla osób fizycznych obowiązująca regulacja nie daje odpowiedzi na zasadnicze pytanie - co dzieje się z rachunkiem po śmierci jego współposiadacza. Mimo że rozwiązaniem zastępczym, które mogłoby z powodzeniem ujednolicić praktykę bankową w tym zakresie, zdaje się powszechne regulowanie tego rodzaju sytuacji w treści umów bankowych, należy stwierdzić, iż najbardziej pożądana byłaby nowelizacja przepisów w ramach kompleksowego uregulowania przedmiotowej materii cywilnoprawnej w ramach k.c. W szczególności z aprobatą należy odnieść się do proponowanej już nowelizacji poprzez dodanie w tytule XX art. $733^{1}$ k.c., który stanowiłby, iż w razie braku odmiennego postanowienia stron umowa rachunku wspólnego wygasa po śmierci współposiadacza. Aktualnie zaś należy odnieść się krytycznie do koncepcji, które przewidują wstąpienie spadkobierców w miejsce zmarłego jako stron umowy, gdyż stanowi to nadmierne ograniczenie prawa żyjącego posiadacza do dysponowania rachunkiem. Oczywiste jest również, iż żadna ze stron nie będzie zainteresowana kontynuowaniem umowy rachunku wspólnego w tym kształcie. Dlatego też najbardziej uzasadnione wydaje się przyjęcie, iż w przypadku śmierci współposiadacza rachunek wspólny traci swój byt.

\section{Bibliografia}

\section{Akty prawne}

Dyrektywa Rady 92/91/EWG z 3.11.1992 r. dotycząca minimalnych wymagań mających na celu poprawę warunków bezpieczeństwa i ochrony zdrowia pracowników w zakładach górniczych wydobywających kopaliny otworami wiertniczymi, Dz. Urz. WE L348 z 28.11.1992 r., s. 9 z późn. zm.

Dyrektywa Rady 92/104/EWG z 3.12.1992 r. w sprawie minimalnych wymagań w zakresie bezpieczeństwa i ochrony zdrowia pracowników odkrywkowego i podziemnego przemysłu wydobywczego. Dz. Urz. WE L 404 z 31.12.1992, s. 10 z późn. zm.

Dyrektywy Parlamentu Europejskiego i Rady 94/22/WE z 30.05.1994 r., w sprawie warunków udzielania i korzystania z zezwoleń na poszukiwanie, badanie i produkcję węglowodorów. Dz. Urz. WE L 164 z 30.06.1994.

Ustawa z 23.04.1964 r. - Kodeks cywilny, Dz.U. 2019, poz. 1145 z późn. zm.

Ustawa z 17.11.1964 r. - Kodeks postępowania cywilnego, Dz.U. 2020, poz. 1575.

Ustawa z 29.08.1997 r. - Prawo bankowe, Dz.U. 2019, poz. 2357 z późn. zm. 
Ustawa z 1.04.2004 r. o zmianie ustawy - Prawo bankowe oraz o zmianie innych ustaw, Dz.U. 2004, nr 91, poz. 870.

Ustawa z 9.06.2011 r. - Prawo geologiczne i górnicze, Dz.U. 2020, poz. 1064.

Ustawa z 10.06.2016 r. o zmianie ustawy kodeks rodzinny i opiekuńczy oraz niektórych innych ustaw, Dz.U. 2016, nr 1177.

Ustawa z 4.10.2018 r. o pracowniczych planach kapitałowych, Dz.U 2020, poz. 1342.

Ustawa z 16.06.2019 r. o zmianie ustawy o pracowniczych planach kapitałowych, ustawy o organizacji i funkcjonowaniu funduszy emerytalnych oraz ustawy - Prawo bankowe, Dz.U. 2019, nr 1074.

\section{Orzecznictwo}

Postanowienie SN z 7.11.1967, I CZ 97/67, OSNCP i Uz (1968), nr 8-9, poz. 145.

Wyrok NSA z 4.06.2013 r., II FSK 1534/12, Lex nr 1335247.

Wyrok SA w Katowicach z 28.10.2010 r., III AUa 773/10, Lex nr 1001389.

Wyrok SA w Poznaniu z 30.06.2010 r., I ACa 504/10, Lex nr 756620.

Wyrok SA w Warszawie z 17.10.2007 r., III AUa 961/07, Lex nr 439385.

Wyrok SA w Warszawie z 11.01.2017 r., V Ca 919/16. Pobrano z http://orzeczenia.warszawa. so.gov.pl/content/\$N/154505000001503_V_Ca_000919_2016_Uz_2017-0203_001 (30.06.2020).

Wyrok SA w Warszawie z 27.02.2019 r., III AUa 895/17, Lex nr 2686510.

Wyrok SO w Tarnowie z 15.03.2017, I C 908/16. Pobrano z http://orzeczenia.tarnow. so.gov.pl/content/\$N/152020000000503_I_C_000908_2016_Uz_2017-03-15_001 (01.06.2020).

Wyrok SO w Warszawie z 26.06.2017 r., XIII U 2662/16. Pobrano z http://orzeczenia.warszawa.so.gov.pl/content/\$N/154505000003918_XIII_U_002662_2016_Uz_201708-02_001 (30.06.2020).

Wyrok SO w Warszawie z 17.05.2017 r., XIII U 7/17. Pobrano z http://orzeczenia.warszawa. so.gov.pl/content/\$N/154505000003918_XIII_U_000007_2017_Uz_2017-0606_001(30.06.2020).

\section{Literatura}

Dobrzeniecka, A. (2016). Rachunki wspólne a upadłość konsumencka. Monitor Prawa Bankowego, 3, 98-103.

Drela, M., Stangret-Smoczyńska A. (2010). Wspólny rachunek bankowy (uwagi na tle projektowanych zmian). Państwo i Prawo, 6, 55-66.

Gołaczyński, J. (2010). W: E. Gniewek, P. Machnikowski (red.), Kodeks cywilny. Komentarz. Warszawa: C.H. Beck, Legalis, komentarz do art. 725 k.c. 
Góral, L., Karlikowska, M., Koperkiewicz-Mordel, K. (2006). Polskie prawo bankowe. Warszawa: Wydawnictwo Prawnicze Lexis-Nexis.

Kawulski, A. (2013). Prawo bankowe. Komentarz. Warszawa: Wydawnictwo Prawnicze Lexis-Nexis.

Kowalewska, E., Pisarewicz, P. (2017). Wybrane zagadnienia regulacji prawa bankowego i nadzoru nad rynkiem finansowym w kontekście praktyki ochrony klientów sektora bankowego. Zarzadzanie i Finanse. Journal of Management and Finance, 15(2/1), 29-48.

Mazur, L. (2007). Umowa rachunku bankowego. Komentarz. Warszawa: C.H. Beck.

Mikos-Sitek, A., Zapadka, P. (2011). Polskie prawo bankowe. Wybrane zagadnienia. Warszawa: Wydawnictwo Wolters Kluwer.

Monkiewicz, A. (2014). Wspólny rachunek bankowy - ograniczenia podmiotowe oraz skutki ustalenia wielkości udziałów współposiadaczy dla potrzeb postępowania egzekucyjnego. Przeglad Sądowy, 3, 24-34.

Niezbecka, E. (2014). W: A. Kidyba (red.), Kodeks cywilny. Komentarz, Warszawa: Wydawnictwo Wolters Kluwer, Lex, komentarz do art. 725 k.c.

Nowacki, A. (2016). W: K. Osajda (red), Kodeks cywilny. Komentarz, Warszawa: C.H. Beck, Legalis, komentarz do art. 725 k.c.

Nowak, M. (2018). Problematyka umów rachunku bankowego - wybrane zagadnienia. Wrocławskie Studia Erazmiańskie, 12, 561-572.

Ofiarski, Z. (2017). Wspólny rachunek bankowym w prawie geologicznym i górniczym Przeglad Ustawodawstwa Gospodarczego, 5, 2-7.

Ogiegło L. (2011). W: K. Pietrzykowski (red.), Kodeks cywilny. Komentarz (t. 2). Warszawa: C.H. Beck, Legalis, komentarz do art. 725 k.c.

Pisuliński, J. (2005). Każda ustawa rzepkę sobie skrobie. Rzeczpospolita, 30 listopada, Lex. Pisuliński, J. (2012). W sprawie systematyki części szczegółowej prawa zobowiązań (głos w dyskusji), Transformacje Prawa Prywatnego, 1, 15-23.

Rogoń, D. (2005). W: F. Zoll (red.), Prawo bankowe. Komentarz (t. 1, s. 430). Kraków: Zakamycze, Legalis.

Pyzioł, W. (1997). Umowa rachunku bankowego (s. 79). Warszawa: Wydawnictwo Prawnicze PWN.

Pyzioł, W. (2007). W: E. Fojcik-Mastalska (red.), Prawo bankowe. Komentarz (s. 183). Warszawa: Wydawnictwo Prawnicze Lexis-Nexis.

Pyzioł, W., Szumański, A., Weiss, I. (2018). Prawo spółek. Warszawa: C.H. Beck.

Radwański, Z., Panowicz-Lipska, J. (2005). Zobowiązania - część szczegółowa. Warszawa: C.H. Beck, Legalis.

Sikorski, G. (2006). Egzekucja z rachunków bankowych. Sopot: Currenda, Lex. Smykla, B. (2011). Prawo bankowe. Komentarz (wyd. 2). Warszawa: C.H. Beck, Legalis. 
Sychowicz, M. (2017). W: J. Gudowski (red.), Kodeks cywilny. Komentarz (t. 5: Zobowiazania. Część szczegółowa). Warszawa: Wydawnictwo Wolters Kluwer.

Zwyrtek, M. (2006). Cash pooling po polsku. Monitor Podatkowy, 8. Pobrane z https:// czasopisma.beck.pl/monitor-podatkowy/artykul/cash-pooling-po-polsku/ (30.06.2020).

\section{Źródła internetowe}

BFG. (2018). Informacja dotycząca wykazywania przez banki wierzytelności spółek cywilnych w systemie wyliczania, 14.04.2018. Pobrano z https://www.bfg.pl/wp-content/ uploads/informacja-dotyczaca-wykazywania-przez-banki-wierzytelnosci-spolek-cywilnych-w-systemie-wyliczania.pdf (25.06.2020).

KNF. (2016). Pismo KNF z 16.11.2016 r., KNF, DOK/WPRII/075/6/1/2016/AC. Pobrano z https://www.knf.gov.pl/knf/pl/komponenty/img/Nowe_obowiazki_informacyjne_bankow_i_skok_5-11-2016_48788.pdf (25.06.2020).

NBP. (b.d.). Pismo NBP z 12.07.2001 r. NB-BPN-III-PMB-526-395/01. Pobrano z https:// sip.lex.pl/orzeczenia-i-pisma-urzedowe/pisma-urzedowe/nb-bpn-iii-pmb-526-395-01-spolka-cywilna-pismo-wydane-184562750 (25.06.2020).

Projekt zmian k.c. z 24.11.2008 r., proj. 08929 artv. Pobrano z www.ms.gov.pl (17.03.2012).

Uzasadnienie do projektu ustawy o zmianie Kodeksu cywilnego i niektórych innych ustaw, bip.kprm.gov.pl/ftp/kprm/dokumenty/0810031luz.pdf (17.03.2012).

Związek Banków Polskich. (b.d.). Co dzieje się z naszym kontem bankowym po śmierci? Pobrano z http://www.brdubezpieczenia.pl/images/Artykuly/Warto_wiedziec/ CO-SI-DZIEJ-Z-KONTEM-PO-MIERCI.pdf (30.06.2020).

Związek Banków Polskich. Pobrano z www.zbp.pl, Raporty i publikacje - materiał archiwalny (17.03.2012).

\section{Streszczenie}

Celem niniejszego opracowania jest ocena obowiązujących regulacji dotyczących umowy rachunku wspólnego, ze szczególnym uwzględnieniem problemu dziedziczenia udziału zmarłego współposiadacza. Zmierzono się z odpowiedzią na pytanie, czy obowiązujące przepisy rozstrzygają kwestię losów takiego rachunku po śmierci jednego z posiadaczy oraz zaproponowano kierunki zmian legislacyjnych w tym zakresie. Zasygnalizowano również potrzebę nowelizacji przepisów w przedmiocie rozszerzenia kręgu posiadaczy rachunku wspólnego o kategorię osób prawnych.

SŁowA KLUCzowE: rachunek wspólny, rachunek bankowy, dziedziczenie rachunku wspólnego. 


\section{Summary}

The purpose of the present article is the evaluation of regulations regarding joint bank accounts, in particular with reference to the issue of inheriting the share of the deceased holder. This study tackles the issue of whether the current regulations provide an answer to the question if the account should continue as sole ownership or the account agreement should be terminated. It also indicates the most requisite amendments in the regulations to clarify the issue stated above, as well as some postulates towards enlargement of the group of prospective joint account holders by adding the category of legal persons.

KEYWORDS: joint account, bank account, inheriting joints accounts.

\section{Nota o autorze}

Katarzyna Bujas - mgr, absolwentka studiów doktoranckich na Wydziale Prawa i Administracji Uniwersytetu Śląskiego w Katowicach; główne obszary działalności naukowej: prawo cywilne, prawo prywatne międzynarodowe, prawo spadkowe, prawo bankowe, europejskie prawo spadkowe; ORCID: 0000-0002-9823-8927. 